\title{
Prologue
}

Whenever people learn that most of my work concerns mothers and motherhood, they have one predictable question: Am I a mother? Learning that I'm not leads to further questions. If my interest in mothers does not come from personal experience, then surely I must be drawn to study mothers either because I'm trying to decide whether to become one or (increasingly the assumption as I have advanced in age) because my research focus represents a way to compensate for losing my chance to be a mother. When I reveal my devotion to teaching and the pleasure I take in working with young people, these same inquisitors are convinced that they have located yet more evidence that I need to resolve my nonmaternal state. My students (and very likely my many cats, as well) are obvious child surrogates.

But a desire to be a mother is not what drives my work. I have never wished to be a mother and have little firsthand experience with small children, My feelings about motherhood when I began to study it were not unlike those of any other anthropologist encountering a strange and temporarily opaque local custom.

An incident that occurred while I was conducting fieldwork with Latina immigrants in San Francisco illustrates the abyss that I perceived between myself and women who were mothers. I was visiting with one of my informants, a young mother of three, recently arrived from Mexico. Several of her relatives were gathered in her home, all women in their twenties (as I was at the time) and all mothers. For most of the afternoon, the five mothers and I conversed in the kitchen while their seventeen children, all under the age of five, played in the next room. From the noises I could hear, I could only assume that the children were 
systematically destroying every item of furniture in the room, but not before spilling Cokes and scattering food in cvery direction. As the afternoon wore on, I found it increasingly difficult to concentrate on anything besides the terrible headache I was getting. The women appeared to enjoy the tumult, and energetically competed with each other over whose child was most rambunctious. When not discussing their children, they directed their attention to their concerns about me and the fact that I had no children. How did I cope with the loneliness? How would I deal with the isolation I would undoubtedly face as I grew older? Who would take care of me in later years? While I was totally overwhelmed by the immediate assault these children mounted against my sanity, the women's focus was on the ways those same children connected them to the world and eventually would grow to perform many essential roles for them.

This story is not unusual. Mothers everywhere learn to cope calmly with the interruptions and noise their children produce. But what struck me at the time was that the meaning of motherhood for these Latina women was not at all the same as what I felt about it. Like them, I was a woman, but unlike them, I did not build my expectations for the future around motherhood. My interest in studying mothers was sparked then not by my resemblance to these women but by my acute sense of difference from them. For the Latinas, motherhood provided a connection - though an indirect one at best- to their cconomic future. Motherhood might mean many other things to me, but I knew it would never mean this.

My work with Latina immigrants convinced me that looking at motherhood as a strategy would be a productive way to examine motherhood in other populations as well. How would the strategies differ for women with different economic constraints and with different beliefs about the inevitability of motherhood? I knew a number of lesbian mothers through my involvement in the lesbian community. How would women who were not expected to be mothers make sense of their maternal situations? What kinds of strategies would they construct to deal with the problems they faced, and how would they view the future? 


\section{Prologue [xv]}

At the time I began to consider writing a research proposal on lesbian mothers, I was engaged in a personal struggle over the kind of career I would have as an anthropologist. In 1969, midway through my career in graduate school, ferminism emerged as a force in my life. More than any of my previous political commitments, the women's movcment came not only to shape my "personal" life but to define my academic interests. As a result, my progress in graduate school and in my early professional years became increasingly tied to the development of an anthropology of women. ${ }^{1}$

Like others involved in the development of the new feminist academic specializations, I felt I should generate knowledge that would help to eradicate sexism and patriarchal domination; I scrutinized each prospective research project for its potential applicability to what seemed to be the central problems facing women out in the world. Furthcr, as a Icsbian, I felt a special obligation to focus my energies on a "lesbian project"; at the same time, I was concerned, not without reason, that my fledgling career might prove to be a casualty of this kind of commitment.

Studying lesbian mothers seemed to meet all the criteria I had for turning my research into a meaningful social contribution, and for devising a way to maintain an explicitly feminist, and possibly lesbian feminist, agenda in my work. There was an obvious need to generate knowledge about this highly stigmatized population, first, to make its existence visible, and second, to help dispel the stereotypes that prevailed in custody challenges and that could be considered responsible for injustices in the resolution of these cases. I felt that this work not only would be the next logical step in my carcer but would turn it toward purposes nobler than mere scholarship.

But when I first began planning the research, I found myself being rather secretive about what I was up to. I had landed a minor research position, my first job after completing graduate school, and when I first tentatively mentioned my new interests to a senior colleague, I got the distinct impression that my topic created some discomfort. Convinced that I could not possibly conduct such unconventional research in a regular university department, I began working on a 
grant proposal with the development office of a private research organization known for sponsoring a range of sometimes radical research projects.

While I was still developing the preliminary version of my proposal, I moved to a different department at my university for a year of postdoctoral training. A senior colleague there, not coincidentally a lesbian, showed great interest in my work, and immediately offered me the resources of her department along with the opportunity to be the principal investigator (PI) on the grant, should it be funded. This was a significant offer, since junior researchers in my position often had to content themselves with subordinate status on their own projects, while senior faculty members served as PIs, sometimes enhaneing their reputations with work done by the younger researchers. The offer also carried with it, at least at that time, the possibility of a future academic affiliation, since other faculty there had tended to be offered appointments only after serving an apprenticeship of sorts during several years of "grant-hustling." With this offer in hand, I extricated my project from the private research organization and began to prepare a final revision of my proposal.

My senior colleague, now my mentor, also advised me about how to apply for a grant. She demystified the process of approaching funding agencies, advised me about those I should target and how to get assistance from agency staff, and recommended that I think about doing a project far larger and more ambitious than the one I had originally contemplated.

Her encouragement, and that of other colleagues, made me feel that I had come of age as a scholar. I was thirty years old, one year out of graduate school, and very self-conscious about being a lesbian in a professional environment. My ideas not only were being taken seriously but were being received enthusiastically by an audience of seasoned researchers. A department research seminar took up my sampling design; various colleagues offered suggestions and amendments, and no one suggested that this topic was too hot to handle or a threat to the respectability of the department. Although I never discussed my personal stake in a topic concerning lesbians, it seemed clear to me that my colleagues understood that I was a lesbian researcher working on a 


\section{Prologue [xvii}

lesbian topic, and that they found nothing wrong with that. The mere fact that the project could be developed as a conventional research grant proposal meant that not only the study but I myself had become legitimate.

I now understand that the exigencies of applying for, and later recciving, federal research funds had a powerful effect on the shape of the research I did on lesbian mothers. I applied to the National Institute of Mental Health (NIMH) during a time when the Institute was regularly supporting controversial social research. My application was considered by a committee at the NIMH charged with supporting research on something loosely labeled "social problems." This funding pattern depended on a broad construction of "mental health" as including the ordinary round of social behavior, particularly with reference to populations at risk for some kind of discrimination or economic deprivation. ${ }^{2}$

Scholars on the review committee were known to be primarily sociologists, social psychologists, and psychiatrists; their preference was for highly quantified hypothesis-testing designs, with standardized research instruments producing data amenable to statistical manipulation. It was clear that proposals for small-scale ethnographic studies of communities, the sort of thing I had been trained to do, would not fare well in this environment. As I became committed to actually getting the project funded, I accommodated the notion that I would have to do a large comparative study and so would have to include a control group of heterosexual mothers.

After some consultation by phone, I submitted a preliminary proposal to a senior staff member of the Institute. He showed great interest in me and my project, offering to assist me with the logistics of grant writing and with the sensitive politics of submitting a "gay" proposal to a federal agency. At the time, it never occurred to me that this intensive coaching might go beyond the usual requirements of his position, but months later, when we happened to meet, I realized that he was gay too. Among his suggestions was the advice that I change the title of the proposal so that the "L-word" would not appear in either the title or the abstract. His concern was that Senator William Proxmire or one of his minions, then on the lookout for federally 


\section{[xviii] Prologue}

funded research that could be ridiculed with the notorious Golden Fleece Award, would be less likely to notice the proposal if its title were sufficiently bland. The title became "Single Mothers: Adaptive Strategies."

I offer this account of the genesis of the project that became this book less in a confessional spirit than out of a commitment to the notion that scholarship is never simply an intellectual enterprise. I began thinking about studying lesbian mothers in 1975, submitted a proposal in 1976, carried out research in 1977 to $198 \mathrm{I}$, and have struggled since then to transform an investigation done at a particular historical and personal moment into a work that would speak to a changing world and reflect my changing voice.

The years it has taken mc to produce this book are also years during which uncertain employment and competing obligations battled with my desire to share the worlds of lesbian mothers with the public. Two cross-country moves, a period of employment as a typist, selfdoubt, and constant reevaluation of the meaning of the project fed into what appeared to be a pattern of procrastination. But I now understand that I could not have finished any sooner. Not only did I have to wait for intellectual currents to offer me a way to jettison the positivistic stance promoted by the federal grant structure, but I could not complete this book before the "L-word" had moved toward becoming a complex and highly differentiated concept. With the growth of the new field of lesbian and gay studies, the need for secrecy and subterfuge is slipping into history, and while I know that our struggles are not over, it now seems that a promising future lies ahead. 


\section{Lesbian Mothers}


